\title{
THE RELATIONSHIP OF MINIMUM WAGE, INVESTMENT, GDRP, AND TECHNOLOGY INDEX ON INDONESIAN LABOR ABSORPTION
}

\author{
Siti Safi'atul Ummah*1(D) \\ Ach. Yasin ${ }^{2}$ \\ 1,2 Fakultas Ekonomi dan Bisnis, Universitas Negeri Surabaya
}

\begin{abstract}
Labor issues become an obstacle to the development process in a country. This problem arises due to a lack of employment opportunities, so that the existing workforce is not maximally absorbed. This problem is not spared from several development factors including the minimum wage, investment, GDRP and technology index. With the aim of knowing the influence of the minimum wage, investment, GDRP and technology index variables with the Indonesian labor absorption variable in 2015-2019. Using secondary data obtained from BPS Indonesia and using panel data regression analysis techniques with the Fixed Effect model as the selected model and using classical assumption tests and hypothesis testing. The results of the hypothesis test show that the influence of the minimum wage, investment, GDRP and technology index variables has an effect on the labor absorption variable simultaneously. The magnitude of the effect $\left(R^{2}\right)$ by all independent variables shows that the minimum wage, investment, GDRP and technology index have an effect of $99.82 \%$ on the dependen variable (labor absorption).
\end{abstract}

Keywords: Minimum Wage, Investment, GRDP, Technology Index, Labor Absorption

\section{ABSTRAK}

Masalah ketenagakerjaan menjadi penghambat proses pembangunan di negara Indonesia. Permasalahan ini muncul karena kurangnya lapangan pekerjaan, sehingga tenaga kerja yang ada tidak terserap secara maksimal. Permasalahan ini tidak luput dari pengaruh beberapa faktor pembangunan diantaranya yaitu ada upah minimum, investasi, PDRB dan indeks teknologi. Penelitian ini bertujuan untuk mengetahui adanya pengaruh antara variabel upah minimum, investasi, PDRB dan indeks teknologi dengan variabel penyerapan tenaga kerja Indonesia di tahun 2015-2019. Menggunakan data sekunder yang didapat dari BPS Indonesia dan menggunakan teknik analisis regresi data panel dengan model Fixed Effect sebagai model yang terpilih dan menggunakan uji asumsi klasik dan uji hipotesis. Hasil dari uji hipotesis menunjukkan secara parsial upah minimum dan PDRB tidak berpengaruh terhadap penyerapan tenaga kerja, sementara investasi dan indeks teknologi berpengaruh positif dan signifikan terhadap penyerapan tenaga kerja di Indonesia pada tahun 2015-2019. Sedangkan secara simultan menunjukkan adanya pengaruh antara variabel upah minimum, investasi, PDRB dan indeks teknologi terhadap variabel penyerapan tenaga kerja secara bersamaan. Besarnya pengaruh yang ditimbulkan $\left(R^{2}\right)$ oleh semua variabel independen menunjukkan bahwa upah minimum, investasi, PDRB dan indeks teknologi memberikan pengaruh sebesar $99,82 \%$ terhadap variabel dependen (penyerapan tenaga kerja).

Kata Kunci: Upah Minimum, Investasi, PDRB, Indeks Teknologi, Penyerapan Tenaga Kerja

\section{RIWAYAT ARTIKEL}

Tanggal Masuk:

28 Februari 2021

Tanggal Revisi:

25 April 2021

Tanggal Diterima:

3 Juni 2021

Tersedia Online:

25 Juni 2021

*Korespondensi:

Siti Safi'atul Ummah

E-mail:

siti.17081324042@

mhs.unesa.ac.id

JIET (Jurnal IImu Ekonomi Terapan) p-ISSN: 2541-1470; e-ISSN: 2528-1879

DOI: $10.20473 /$ jiet.v6i1.26553

Open access under a Creative Commons Attribution-ShareAlike 4.0 International

(CC BY-SA) 


\section{Pendahuluan}

Pembangunan merupakan pertumbuhan ekonomi yang dapat diukur dari perubahan aspek lain dalam perekonomian seperti perkembangan pendidikan, perkembangan teknologi, perkembangan kemahiran tenaga kerja. Pada dasarnya pembangunan di suatu negara atau di daerah merupakan proses hubungan antara berbagai variabel diantaranya sumber daya manusia, teknologi, sumber daya alam, modal dan lain sebagainya. Didalam negara berkembang masalah yang menghambat proses pembangunan adalah permasalahan mengenai ketenagakerjaan yaitu tingginya jumlah pengangguran, pertumbuhan penduduk yang semakin meningkat dan upah yang rendah. Jumlah pengangguran yang bertambah terus menerus akan berpengaruh terhadap kesejahteraan masyarakat (Sasana, 2009). Permasalahan ini muncul karena adanya ketidaksesuaian antara permintaan dan penawaran tenaga kerja, sehingga tenaga kerja yang ada tidak terserap secara maksimal. Perkembangan permintaan dan penawaran tenaga kerja dapat berhubungan dengan beberapa faktor pembangunan lain yaitu upah minimum, investasi, PDRB dan indeks teknologi.

Permasalahan mengenai penyerapan tenaga kerja berkaitan erat dengan kebijakan upah minimum. Dalam Undang-Undang Republik Indonsia nomor 13 Tahun 2003 tentang ketenagakerjaan menyebutkan bahwa upah adalah hak pekerja/buruh yang diterima dan dinyatakan dalam bentuk uang sebagai imbalan dari pengusaha atau pembeeri kerja kepada pekerja/buruh yang ditetapkan dan dibayarkan menurut suatu perjanjian kerja, kesepakatan, atau peraturan perundang-undangan, termasuk tunjangan bagi pekerja/buruh daan keluarga atas suatu pekerjaan dan/jasa yang telah dilakukan. Teori klasik menyatakan apabila upah meningkat mengakibatkan permintaan bahan pokok meningkat karena adanya pertumbuhan penduduk, sehingga produsen akan menambah tenaga kerja untuk mengelola jumlah produksinya (Jhingan, 2016). Kenaikan upah menyebabkan penurunan kuantitas permintaan tenaga kerja. apabila tingkat upah mningkat sedangkan harga input lain tetap, maka harga tenaga kerja lebih tinggi dari pada input lain. Hal ini lah yang mendorong produsen untuk mengurangi penggunaan tenaga kerja yang harganya lebih tinggi dari input lain untuk mempertahankan keuntungan yang maksimum (Kuncoro, 2002).

Bukan hanya upah minimum, PDRB (Produk Domestik Regional Bruto) juga menjadi salah satu indikator pembangunan. Mankiw (2006) mengatakan bahwa hukum Okun (Okun's Law) menjelaskan tentang pengaruh PDRB atas penyerapan tenaga kerja, yaitu jika PDRB disuatu wilayah mengalami peningkatan mengakibatkan penyerapan tenaga kerja di wilayah tersebut mengalami peningkatan juga. Dengan ini memperlihatkan bahwa PDRB mempengaruhi penyerapan tenaga kerja dengan pengaruh yang positif. Dalam meganalisis hukum Okun para ekonom mengkaji koefisien Okun merupakan suatu komponen penting dengn beberapa alasan. Pertama, jika variabel kebijakan menggunakan tingkat pengangguran, maka koefisien Okun bisa diinterprestasikan menjadi besaran target perekonomian. Yang kedua, koefisen Okun bermanfaat untuk melihat saat output berada dibawah atau diatas nilai potensinya. Yang ketiga, peramalan output digunakan untuk menyatakan peramalan dari tingkat pengangguran (Sinclair, 2005). PDRB dapat berpengaruh terhadap jumlah tenaga kerja yang berasumsi jika PDRB naik akan menaikkan jumlah output diantara semua unit di wilayah tersebut. Semakin tinggi nilai output dalam suatu perusahaan maka dapat menodrong perusahaan untuk memperbanyak tenaga kerjanya sehingga bisa meningkatkan produksinya untuk mengejar peningkatan penjulan yang terjadi (Feriyanto, 2014).

Salah satu faktor lain yang menyebabkan terjadinya peningkatan jumlah angkatan kerja yaitu adanya investasi. Investasi menjadi pendorong pertumbuhan ekonomi dan sebagai 83 
sumber menaikkan produksi. Dalam pembangunan fasilitas sarana prasarana bagi masyarakat sering kali menggunakan investasi yang beruapa barang dan modal. Investasi asing yang ada didaerah akan dialokasikan untuk pembangunan prasarana publik dan untuk menyediakan lapangan kerja. Begitu juga dengan investasi dalam negeri, sehingga apapun jenis investasi yang digunakan merupakan hal penting untuk pembangunan suatu negara. Dengan adanya investasi akan meningkatkan penyerapan tenaga kerja melalui penyediaan lapangan kerja. Dalam teori Harrod-Domar, dengan adanya investasi dapat memperbesar kapasitas produksi, sehingga mengakibatkan adanya penambahan tenaga kerja (Jhingan, 2016).

Teknologi berperan penting dalam industrialisasi. Untuk menghambat masuknya perusahaan pesaing digunakanlah teknologi yang tepat untuk meningkatkan daya saing produk, selain itu penggunaan teknologi juga akan mendukung adanya inovasi produk. Kemajuan teknologi memungkinkan kegiatan ekonomi yang awal mulanya menggunakan binatang dan manusia menjadi tenaga mesin (Sukirno, 2006). Untuk memberikan nilai tambah dalam industri kreatif saat ini teknologi sangat dibutuhkan untuk melakukan inovasi sebuah produk. Apabila suatu perusahaan menggunakan teknologi padat modal, maka yang terjadi permintaan tenag kerja akan menurun, dan apabila perusahaan memakai teknologi yang padat karya, mengakibatkan peningkatan terhadap jumlah permintaan tenaga kerja (Cahyadi, 2018). Teknologi dengan penyerapan tenaga kerja memiliki hubungan dimana ketika suatu perusahaan memiliki teknologi canggih dan modern didalam proses produksinya maka tenaga kerja yang di butuhkan lebih sedikit karena teknologi ini bisa menggantikan pekerjaan yang tidak bisa dilakukan oleh manusia. Pemilihan dari tenaga kerja ditentukan karena kecanggihan teknologi dalam proses produksi, keadaan penetapan kuota tenaga kerja, karakter pengalaman kerja, perhitungan biaya dan manfaat, serta kompleksitas dan tanggung jawab produksi atau pekerjaan yang dilakukan untuk hasil akhir (Zhaleznikova 2013).

Tabel 1 : UMP, PDRB, Investasi dan Angkatan Kerja Indonesia Tahun 2018-2020

\begin{tabular}{ccccccc}
\hline Tahun & UMP & $\begin{array}{c}\text { PDRB } \\
\text { (miliar) }\end{array}$ & $\begin{array}{c}\text { INVESTASI } \\
\text { (miliar) }\end{array}$ & IPT & TPT & $\begin{array}{c}\text { ANGKATAN } \\
\text { KERJA (juta) }\end{array}$ \\
\hline 2015 & 1.790 .342 & 9.033 .169 & $179.465,9$ & 3,88 & 6,18 & 122,38 \\
\hline 2016 & 1.997 .819 & 9.498 .833 & $216.230,8$ & 4,34 & 5,61 & 125,44 \\
\hline 2017 & 2.142 .855 & 9.995 .225 & $262.350,5$ & 4,99 & 5,33 & 128,06 \\
\hline 2018 & 2.268 .874 & 10.526 .928 & $328.604,9$ & 5,07 & 5,30 & 133,94 \\
\hline 2019 & 2.455 .662 & 11.052 .884 & $386.498,4$ & 5,32 & 5,23 & 136,18 \\
\hline 2020 & 2.672 .371 & 10.719 .911 & $413.535,5$ & - & 7,07 & 138,22 \\
\hline
\end{tabular}

Sumber: BPS Indonesia 2016-2021

Berdasarkan data dari BPS menunjukkan bahwa nilai UMP, investasi dan IPT mengalami kenaikan, namun PDRB mengalami penurunan ditahun 2020 dikarenakan pandemi. Begitu juga dengan jumlah angkatan kerja di Indonesia mengalami kenaikan. Peningkatan angkatan kerja menunjukan adanya penambahan penawaran tenaga kerja didalam pasar tenaga kerja. Meskipun adanya penambahan penawaran tenaga kerja akan tetapi tidak selamanya diikuti dengan terserapnya tenaga kerja atas permintaan tenaga kerja. Hal ini dibuktikan pada tabel 1 , angka pengangguran di indonesia mengalami kenaikan pada tahun 2020. Hal ini berarti menunjukkan adanya kemungkinan kenaikan UMP, investasi dan PDRB tidak berpengaruh terhadap penyerapan tenaga kerja di Indonesia. 
Ada banyak penelitian yang menjelaskan tentang hubungan empiris antara upah, PDRB, investasi dan teknologi terhadap penyerapan tenaga kerja di suatu daerah. Namun hasilnya berbeda, seperti penelitian yang telah dilakukan oleh Ali, et al (2020) dan Indradewa \& Natha (2013) yang hasilnya terdapat pengaruh antara PDRB dengan penyerapan tenaga kerja. Penelitian yang telah dilakukan Widdyantoro (2013) dan Lavianty (2016) tidak ada pengaruh antara variabel investasi dengan variabel penyerapan tenaga kerja. Dalam penelitiannya Rahmawati (2019) dan Hanuraga (2018) ada pengaruh antara upah dengan penyerapan tenaga kerja. Namun berbeda dengan hasil penelitiannya Lavianty (2016) tidak ada pengaruh antara dengan penyerapan tenaga Kerja. Terakhir penelitian dari Hasna (2020) dan Nurfiat \& Rustariyuni (2018) teknologi berpengaruh terhadap penyerapan tenaga kerja.

Dari latar belakang tersebut yang sudah dipaparkan peneliti ingin melakukan penelitian yang sedikit berbeda dengan memasukkan variabel indeks teknologi. Penelitian ini dilakukan dengan tujuan untuk melihat adanya pengaruh anatra variabel upah minimum, investasi, PDRB dan indeks teknologi terhadap variabel penyerapan tenaga kerja yang ada di Indonesia.

\section{Telaah Literatur}

\section{Penyerapan Tenaga Kerja}

Penyerapan tenaga kerja adalah banyaknya jumlah penduduk bekerja yang mengisi lapangan pekerjaan yang tersebar diberbagai sektor. Seiring dengan berlangsungnya demografi maka jumlah dan komposisi tenaga kerja akan terus mengalami perubahan. Dalam penyerapan tenaga kerja, proporsi pekerja merupakan salah satu ukuran untuk melihat potensi dalam sektor perekonomian. Penyerapan tenaga kerja dapat dikatakan sebagai permintaan tenaga kerja, karena terserapnya penduduk bekerja disebabkan adanya permintaan tenaga kerja (Konadi, 2014).

Kesempatan kerja adalah banyaknya orang yang dapat tertampung untuk bekerja pada suatu perusahaan atau instansi. Kesempatan kerja atau yang disebut dengan demand for labour merupakan suatu keadaan yang menggambarkan adanya ketersediaan lapangan kerja yang dapat diisi oleh para pencari kerja. Karena itu kesempatan kerja dapat diartikan sebagai permintaan tenaga kerja. Dalam usaha perluasan kesempatan kerja tidak terlepas dari faktor-faktor lain, seperti pertumbuhan ekonomi, pertumbuhan penduduk dan faktor lainnya. Penduduk yang terserap akan tersebar diberbagai sektor perekonomian dan akan mengalami laju pertumbuhan yang berbeda. Perbedaan inilah akan menyebabkan dua hala yaitu adanya perbedaan laju peningkatan produktivitas kerja dimasing-masing sektor dan terjadi perubhan sektoral, baik dalam penyerapan tenaga kerja maupun dalam kontribusinya dalam pendapatan nasional (Simanjuntak, 2001). Tenaga kerja adalah faktor terpenting dalam suatu proses produksi karena manusia merupakan penggerak bagi seluruh faktor-faktor produksi yang lain seperti faktor tanah, modal dan lain sebagainya. Kebutuhan tenaga kerja benar-benar diperlukan oleh suatu perusahaan.

\section{Upah}

Melalui teori klasik yang menyatakan bahwa upah yang lebih tinggi mengundang pertumbuhan penduduk yang menyebabkan permintaan akan makanan naik sehingga produsen perlu menambah produksinya yaitu dengan menambah jumlah tenaga kerja sebagai pengelola produksi yang dapat dihasilkan (Jhingan, 2016). Sama dengan pasar-pasar lainnya, pasar tenaga kerja juga diatur oleh kekuatan-kekuatan permintaan dan penawaran. Terjadinya ketidak seimbangan antara permintaan dan penawaran tenaga kerja inilah yang akan menentukan tingkat upah (Mankiw, 2006). 


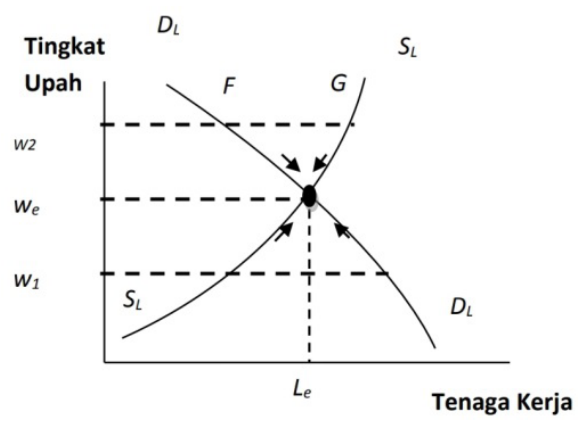

Gambar 1: Penentuan Tingkat Penyerapan Tenaga Kerja Dan Tingkat Upah: Pendekatan Pasar Bebas

Sumber : Todaro (2000)

Pada titik ketika tingkat upah berada di titik ekuilibrium (equiblirium wage rate). Apabila titik upah meningkat berada pada titik $w_{2}$ maka penawaran tenaga kerja melebihi permintaan sehingga persaingan diantara individu untuk memperebutkan pekerjaan akan mendorong turunnya tingkat upah mendekati atau tepat ke titik ekuilibriumnya $\left(w_{e}\right)$. Begitu juga sebaliknya, apabila tingkat upah rendah atau berada pada titik $w_{1}$ maka permintaan tenaga kerja melebihi penawaran yang ada sehingga akan terjadi persaingan antara pengusaha dalam memperebutkan tenaga kerja dan mendorong kenaikan tingkat upah mendekati atau tepat ke titik ekuilibrium (Todaro, 2000).

\section{Investasi}

Investasi dapat didefinisikan sebagai pengeluaran perusahaan untuk membeli perlengkapan dan barang-barang modal untuk menambahkemampuan memproduksi barang dan jasa yang tersedia dalam perekonomian (Sukirno, 2006). Investasi juga dapat didefinisikan sebagai pengeluaran untuk membeli barang-barang modal peralatan-peralatan produksi dengan tujuan untuk mengganti dan juga menambah barang-barang modal dalam perekonomian yang akan digunakan untuk memperoduksi barang dan jasa dimasa yang akan mendatang. Menurut teori Harrod-Domar, dengan adanya penambahan peralatan-peralatan produksi dapat memperbesar kapasitas produksi sehingga akan berdampak pada penambahan tenaga kerja (Jhingan, 2016).

Teori Harrod-Domar mengembangkan teori dari Keynes dengan memberikan peranan utama kepada investasi dalam proses pertumbuhan ekonomi, yang mana investasi memiliki sifat ganda yaitu pertama, investasi menciptakan pendapatan yang merupakan akibat dari permintaan investasi, kedua, investasi dapat memperbesar kapasitas produksi perekonomian dengan cara meningkatkan stok modal yang merupakan akibat dari penawaran investasi (Arsyad, 2010).

\section{PDRB}

Dalam hukum Okun (Okun's Law) menjelaskan tentang pengaruh PDRB terhadap penyerapan tenaga kerja, yaitu apabila PDRB disuatu wilayah meningkat maka penyerapan tenaga kerja di wilayah tersebut akan meningkat juga. Dengan kata lain, PDRB berpengaruh positif terhadap penyerapan tenaga kerja. Dalam meganalisis hukum Okun para ekonom mengkaji koefisien Okun merupakan suatu komponen penting dengn beberapa alasan. Perta- 
$m a$, apabila tingkat pengangguran merupakan variabel kebijakan, maka koefisien Okun bisa diinterprestasikan sebagai besaran target perekonomian. Yang kedua, koefisen Okun bermanfaat untuk mengetahui saat output berada diatas atau dibawah nilai potensinya. Yang ketiga, peramlan output digunakan untuk menyatakan peramalan dari tingkat pengangguran (Sinclair, 2005).

\section{Metode Penelitian}

Penelitian ini menggunakan metode kuantitatif. Penelitian kuantitatif merupakan peneitian yang menggunaan data dalam bentu angka dan analisis statistik (Sugiyono, 2016). Subjek data yang diambil meliputi 34 provinsi yang ada di Indonesia dalam kurun waktu 5 tahun, dari tahun 2015-2019. Jenis data dari penelitian ini yaitu data sekunder yang didapat dari Badan Pusat Satistik (BPS) Indonesia. Metode ini digunakan untuk mendapatkan data UMP, investasi, PDRB, indeks teknologi dan penyerapan tenaga kerja dari semua provinsi di Indonesia pada Statistik Indonesia tahun 2015-2020.

Teknik analisis regresi data panel merupakan teknik analisis yang digunakan. Analisis data panel yaitu kombinasi dari data deret waktu dan data cross-sectional (Widarjono, 2013). Model persamaan regresi data panel yang digunakan adalah :

$$
\log Y=\beta_{0}+\beta_{1} \log x_{1}+\beta_{2} \log x_{2}+\beta_{3} \log x_{3}+\beta_{4} \log x_{4}+\varepsilon
$$

Dimana :

Y

$\beta 0$

$\beta 1, \beta 2, \beta 3, \beta 4$

= penyerapan tenaga kerja

$\mathrm{X} 1$

$=$ konstanta

$\mathrm{X} 2$

$=$ koefisien regresi

$\times 3$

= UMP

$=$ investasi

$\mathrm{X} 4$

$=$ PDRB

e

$=$ indeks teknologi

= eror term

Model logaritma digunakan dalam penelitian ini dengan tujuan untuk melinierkan antara variabel independen dengan variabel dependen. Selain itu, model logaritma juga dapat mengubah data yang awalnya berdistribusi tidak normal menjadi distribusi normal.

Penelitian ini menggunakan program eviews 10 untuk memfasilitasi pengujian. Medel data dipilih melalui 3 pengujian yaitu Polled least square, model Fixed Effect dan model Random Effect untuk penggunaan model regresi data panel yang sesuai dipenelitian ini. Untuk menentukan model regresi data panel yang sesuai dilakukan dengan Uji Chow dan Uji Hausman. Uji Chow dilakukan untuk menentukan model yang tepat digunakan antara Polled least square model dengan model Fixed Effect dengan menggunakan hipotesis $\mathrm{HO}$ : Polled least Square model, dan $\mathrm{H} 1$ : model Fixed Effect. Apabila hasil yang diperoleh probabilitas $\mathrm{F}$ lebih besar dari nilai signifikan 0,05 maka Polled least square model yang terpilih. Dan begitu sebaliknya, apabila hasil yang diperoleh probabilitas $F$ kurang dari nilai signifikan 0,05 maka model Fixed Effect yang terpilih. Uji Hausman dilakukan untuk menentukan model yang tepat digunakan antara model Random Effect dengan model Fixed Effect dengan menggunakan hipotesis H0: model Random Effect, dan H1: model Fixed Effect. Apabila hasil yang diperoleh probabilitas $\mathrm{F}$ lebih besar dari nilai signifikan 0,05 maka model Random Effect yang terpilih. Dan begitu sebaliknya, apabila hasil yang diperoleh probabilitas $F$ kurang dari nilai signifikan 0,05 maka model Fixed Effect yang terpilih. 
Agar model regresi data panel dapat diestimasi secara efektif, maka dilakukanlah uji asumsi klasik yaitu uji normalitas, uji multikolinieritas, uji heterokedastisitas, dan juga uji autokorelasi. Uji hipotesis yang bertujuan untuk mengetahui secara parsial pengaruh dari variabel independen atas variabel dependen dilakukan dengan uji $t$, dan untuk mengetahui apakah terdapat pengaruh antara seluruh variabel independen terhadap variabel dependen dengan bersamaan maka menggunakan uji F. Setelah dilakukannya uji asumsi klasik dan telah terdistribusi normal, maka data tersebut dianalisa dengan menggunakan metode regresi data panel dengan mengacu pada rumusan hipotesis yaitu didga adanya pengaruh antara variabel upah minimum, investasi, PDRB dan indeks teknologi terhadap penyerapan tenaga kerja.

Untuk mengetahui diterima atau ditolaknya rumusan hipotesis maka dilakukan uji sebagai berikut:

1. Ujit

Uji t dilakukan untuk mengetahui apakah terdapat atau tidak pengaruh dari masing-masing variabel independen terhadap variabel dependen yang diuji pada tingkat signifikansi 0,05 (5\%). Dan juga untuk menguji apakah hipotesis yang diajukan diterima atau ditolak, dengan cara membandingkan antara dengan, sehingga dapat ditarik kesimpulan bahwa masing-masing variabel independen secara parsial berpengaruh terhadap variabel dependen dengan kriteria berikut ini :

$$
\begin{aligned}
& \text { Apabila } t_{\text {hitung }}>t_{\text {tabel }} \text { maka H1 diterima dan Ho ditolak } \\
& \text { Apabila } t_{\text {hitung }}<t_{\text {tabel }} \text { maka H1 ditolak dan Ho diterima }
\end{aligned}
$$

2. Uji F

Uji F dilakukan untuk mengetahui apakah terdapat pengaruh antara semua variabel independen terhadap variabel dependen secara simultan. Berdasar data dari BPS keadaan UMP, investasi dan IPT di Indonesia pada 5 tahun terakhir selalu meningkat, akan tetapi PDRB menglami penurunan ditahun 2020 dikarenakan adanya pandemi. Disamping itu angka pengangguran di indonesia juga mengalami peningkatan ditahun 2020. Uji F dilakukan pada tingkat signifikansi 0,05 (5\%), yang artinya semua variabel independen yang diteliti secara bersama-sama berpengaruh atau tidak terhadap variabel dependen dengan kriteria sebagai berikut

$$
\begin{aligned}
& \text { Apabila } F_{\text {hitung }}>F_{\text {tabel }} \text { maka } \mathrm{H} 1 \text { diterima dan Ho ditolak } \\
& \text { Apabila } F_{\text {hitung }}<F_{\text {tabel }} \text { maka } \mathrm{H} 1 \text { ditolak dan Ho diterima }
\end{aligned}
$$

\section{Hasil dan Pembahasan}

\section{Hasil Penelitian}

\section{Estimasi Model Regresi Data Panel}

Untuk memilih model regresi data panel yang paling baik digunakan dalam penelitian ini, maka dilakukan 3 metode pengujian yaitu Pooled Least Square, Fixed Effect Model dan Random Effect Model. Hasil dari pengujiannya sebagai berikut :

\section{Uji Chow}

Uji Chow dilakukan untuk memilih metode yang paling tepat digunakan antara Fixed Effect Model dan Pooled Least Square. Berdasarkan hasil pengujian diperoleh nilai probabilitas sebesar 0.0000, yang artinya $\mathrm{H} 1$ diterima karena nilai probabilitas lebih kecil jika diband- 
ingkan dengan tingkat signifikan $\alpha 5 \%(0.0000<0.05)$. Maka dapat disimpulkan bahwa Fixed Effect Model lebih tepat untuk digunakan.

2. Uji Hausman

Uji Hausman dilakukan untuk memilih metode yang paling tepat digunakan antara Fixed Effect Model dan Random Effect Model. Berdasarkan hasil pengujian diperoleh nilai probabilitas sebesar 0.0000 , yang artinya $\mathrm{H} 1$ diterima karena nilai probabilitas lebih kecil jika dibandingkan dengan tingkat signifikan $\alpha 5 \%(0.0000<0.05)$. Maka dapat disimpulkan bahwa Fixed Effect Model lebih tepat untuk digunakan.

\section{Uji Asumsi Klasik}

Tujuan dilakukan Uji asumsi klasik yaitu untuk mengetahui apakah terdapat masalah didalam asumsi klasik yang merupakan dasar dalam regresi data panel.

1. Uji Normalitas

Berdasarkan hasil uji normalitas yang menggunakan eviews, diperoleh nilai Jarque-Bera sebesar 3.751892 dengan nilai probabilitas sebesar 0.153210 . Sehingga nilai probabilitas Jarque-Bera lebih besar dari nilai alpha 0.05 , artinya asumsi normalitas terpenuhi dan residual terdistribusi normal. Untuk lebih jelasnya bisa diperhatikan dalam gambar 2 berikut ini:

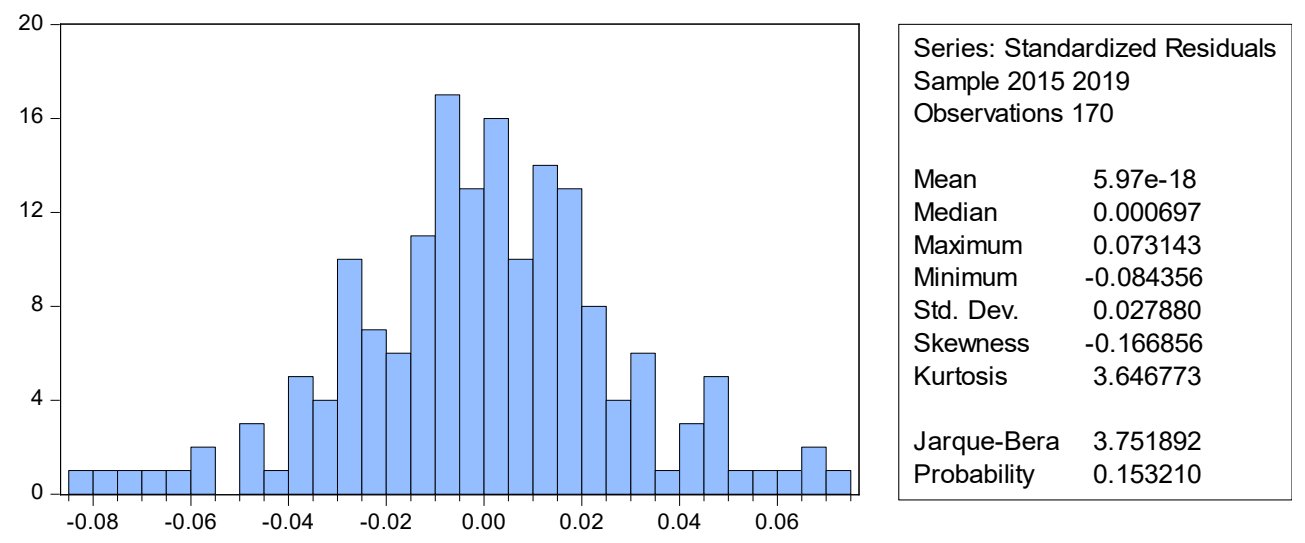

Gambar 2: Hasil Uji Normalitas

Sumber: Data Penelitian, diolah

2. Uji Multikolinieritas

Untuk mendapatkan hasil yang baik, seharusnya tidak terjadi korelasi diantara variabel independen. Apabila nilai koefisien korelasi dimasing-masing variabel independen lebih dari 0.8 maka data terjadi multikolinieritas. Berdasarkan hasil uji multikolinieritas yang sudah dilakukan, menunjukkan bahwa tidak ada nilai koefisien korelasi dari masing-masing variabel independen yang leih besar dari 0.8. Artinya dalam uji ini tidak ada masalah multikolinieritas. Untuk lebih jelasnya bisa diperhatikan dalam tabel 2 berikut ini :

Tabel 2: Uji Multikolinieritas

\begin{tabular}{ccccc}
\hline & X1 & X2 & X3 & X4 \\
\hline X1 & 1.000000 & 0.049284 & -0.023021 & 0.224000 \\
\hline X2 & 0.049284 & 1.000000 & -0.078298 & -0.004504 \\
\hline X3 & -0.023021 & -0.078298 & 1.000000 & 0.145790 \\
\hline X4 & 0.224000 & -0.004504 & 0.145790 & 1.000000 \\
\hline
\end{tabular}

Sumber : Data Penelitian, diolah 


\section{Uji Heteroskedastisitas}

Untuk mendapatkan hasil yang baik dalam uji heteroskedastisitas, seharusnya hasil yang didapat terbebas dari heteroskedatisitas. Apabila nilai dari probabilitas diantara masing-masing variabel indepeenden lebih besar dibandingkan taraf signifikan yaitu 0.05 maka data tidak terjadi heteroskedastisitas. Berdasarkan hasil uji heteroskedastisitas yang dilakukan menunjukkan hasil nilai probabilitas diatas taraf sinifikan yaitu 0.05. Artinya, tidak ada masalah heteroskedastisitas. Untuk lebih jelasnya bisa diperhatikan dalam tabel 3 berikut ini :

Tabel 3: Uji Heteroskedastisitas

\begin{tabular}{ccccc}
\hline Variable & Coefficient & Std. Error & t-Statistic & Prob. \\
\hline C & 0.263685 & 0.671972 & 0.392405 & 0.6954 \\
\hline X1 & 0.008401 & 0.035950 & 0.233682 & 0.8156 \\
\hline X2 & 0.004089 & 0.034533 & 0.118403 & 0.9059 \\
\hline X3 & -0.049869 & 0.026133 & -1.908245 & 0.0586 \\
\hline X4 & 0.059157 & 0.175698 & 0.336698 & 0.0586 \\
\hline
\end{tabular}

Sumber : Data Penelitian, diolah

4. Uji Autokorelasi

Untuk mendapatkan hasil yang baik dalam uji autokorelasi, seharusnya hasil yang didapat adalah tidak ada permasalahan autokorelasi. Uji ini dilakukan menggunakan statistik Durbin Watson (DW). Dan hasil diperoleh nilai Durbin Watson yaitu sebesar 2.076035. Berdasarkan perhitungan yang dilakukan, jumlah observasi $=170$ dan $\mathrm{k}$ (variabel) $=4$, maka nilai $\mathrm{DI}=1.7012$ dan $\mathrm{Du}=1.7979$. Dengan demikian nilai Durbin Watson yaitu 2.076035 terletak pada kaidah keputusan tidak adanya autokorelasi positif maupun autokorelasi negatif, seperti yang terlihat dalam gambar 2 berikut ini :

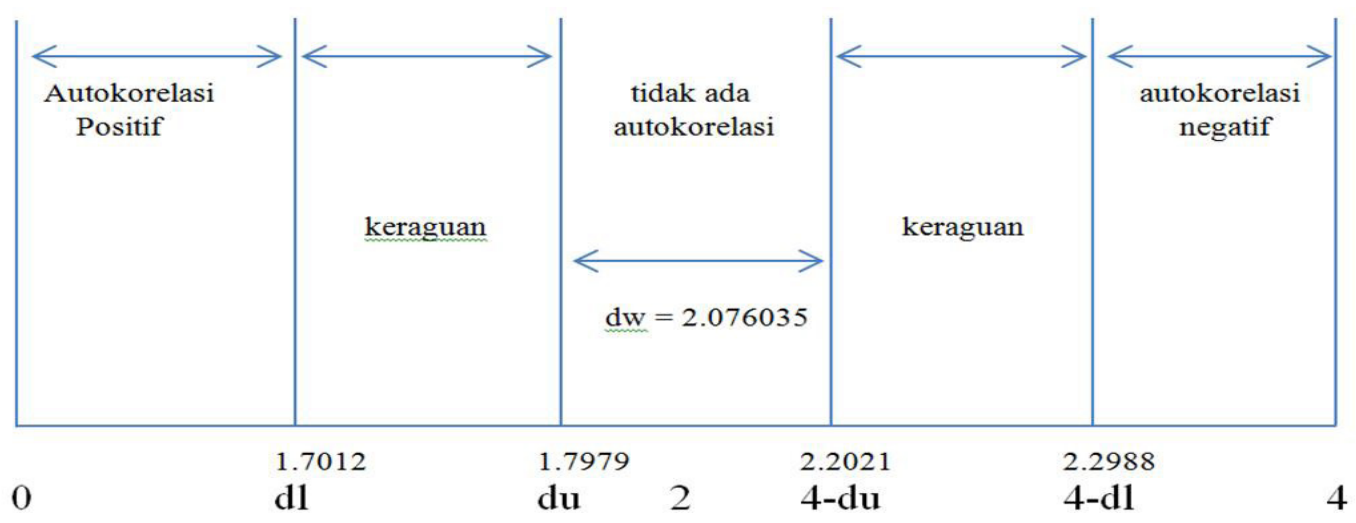

\section{Gambar 3: Hasil Uji Autokorelasi melalui Durbin Watson}

Sumber: Data Penelitian, diolah

\section{Uji Hipotesis}

1. Ujit

Uji t dilakukan untuk menguji apakah variabel independen yaitu upah, investasi, PDRB dan teknologi berpengaruh secara parsial atau masing-masing terhadap variabel dependen yaitu penyerapan tenaga kerja di Indonesia. Kriteria dari Uji t yaitu apabila nilai probabilitas lebih besar dari nilai $\alpha=5 \%$ (prob > 0.05), maka HO diterima. Artinya, variabel independen tidak berpengaruh signifikan terhadap variabel dependen. Begitupun sebaliknya, apabila nilai probabilitas lebih kecil dari nilai $\alpha=5 \%$ (prob > 0.05), maka HO ditolak. Artinya, variabel inde- 
penden berpengaruh signifikan terhadap variabel dependen. Berikut hasil uji t dapat dilihat pada tabel 4 :

Tabel 4: Uji t

\begin{tabular}{clccc}
\hline Variable & Coefficient & Std. Error & t-Statistic & Prob. \\
\hline C & 2380083. & 159823.0 & 14.89199 & 0.0000 \\
\hline X1 & 0.004223 & 0.095295 & 0.044319 & 0.9647 \\
\hline X2 & 0.640027 & 0.282403 & 2.266365 & 0.0251 \\
\hline X3 & 5.989920 & 4.443450 & 1.348034 & 0.1800 \\
\hline X4 & 201721.0 & 55374.89 & 3.642825 & 0.0004 \\
\hline
\end{tabular}

Sumber : Data Penelitian, diolah

a. Upah Minimum

Berdasarkan hasil dari uji t yang sudah dilakukan, diperoleh hasil variabel upah minimum yaitu 0.044319 dengan probabilitas 0.9647 . Artinya nilai probabilitas lebih besar dari nilai $\alpha=0.05(0.9647>0.05)$, sehingga HO ditolak. Artinya variabel upah tidak memiliki pengaruh dan tidak signifikan terhadap variabel penyerapan tenaga kerja di Indonesia.

b. Investasi

Berdasarkan hasil dari uji t yang sudah dilakukan, diperoleh hasil variabel investasi yaitu 2.266365 dengan probabilitas 0.0251 . Artinya nilai probabilitas lebih kecil dari nilai $\alpha=0.05(0.0251<0.05)$, sehingga $\mathrm{HO}$ diterima. Artinya variabel investasi memiliki pengaruh positif dan signifikan terhadap variabel penyerapan tenaga kerja di Indonesia.

c. PDRB

Berdasar dari hasil uji t yang telah dilakukan, diperoleh hasil variabel PDRB sebesar 1.348034 dengan probabilitas 0.1800 . Artinya nilai probabilitas lebih besar dari nilai $\alpha=0.05(0.1800>0.05)$, sehingga HO ditolak. Artinya variabel PDRB tidak memiliki pengaruh dan tidak signifikan terhadap variabel penyerapan tenaga kerja di Indonesia.

d. Indeks Teknologi

Berdasar dari hasil uji t yang telah dilakukan, diperoleh hasil variabel indeks teknologi sebesar 3.64285 dengan probabilitas 0.0004 . Artinya nilai probabilitas lebih kecil dari nilai $\alpha=0.05(0.0004<0.05)$, sehingga $\mathrm{HO}$ diterima. Artinya variabel indeks teknologi memiliki pengaruh positif dan signifikan terhadap variabel penyerapan tenaga kerja di Indonesia.

\section{Uji F}

Dilakukan Uji F bertujuan untuk menguji apakah variabel independen yaitu upah, investasi, PDRB dan teknologi memiliki pengaruh secara simultan atau bersama-sama terhadap variabel dependen yaitu penyerapan tenaga kerja di Indonesia. 
Tabel 5: Uji F

\begin{tabular}{lcll}
\hline Cross-section fixed (dummy variables) & & \\
\hline R-squared & 0.998238 & Mean dependent var & 3549049. \\
Adjusted R-squared & 0.997744 & S.D. dependent var & 5068380. \\
S.E. of regression & 240752.8 & Akaike info criterion & 27.81499 \\
Sum squared resid & $7.65 \mathrm{E}+12$ & Schwarz criterion & 28.51593 \\
Log likelihood & -2326.274 & Hannan-Quinn criter. & 28.09943 \\
F-statistic & 2020.759 & Durbin-Watson stat & 1.219919 \\
Prob(F-statistic) & 0.000000 & & \\
& & & \\
\hline
\end{tabular}

Sumber : Data Penelitian, diolah

Dari hasil Uji F dengan menggunakan hasil regresi data panel metode Fixed Effect diperoleh nilai F-statistik sebesar 2020.759 dengan nilai probabilitas 0.0000 , dan diperoleh nilai sebsar 2.43 pada tingkat signifikansi $\alpha=0.05, k=4$ dan $n=170$. Berdasarkan hasil tersebut F-statistik lebih besar dari $(2020.759>2,43)$ dan probabilitas F-statistik lebih kecil dari tingkat signifikansi $\alpha=0.05(0.0000<0.05)$. Maka dapat disimpulkan bahwa variabel independen yaitu upah minimum, investasi, PDRB dan indeks teknologi mempengaruhi variabel dependen yaitu penyerapan tenaga kerja di Indonesia dalam kurun waktu 2015-2019.

\section{Uji Koefisien Determinasi}

Pengujian selanjutnya setelah memilih model regresi dan mendapatkan model Fixed Efect sebagai model yang sesuai, maka dilakukan pengukuran persentase semua variabel dependen yang dapat dijelaskan oleh variabel independen dalam regresi. Berdasarkan hasil pengujian diatas dapat dilihat pada tabel 5 , diperoleh hasil koefisien determinasi sebesar 0.998238 atau sebesar $99.82 \%$. Artinya dalam variabel upah minimum, investasi, PDRB dan indeks teknologi memiliki kontribusi sebesar $99,82 \%$ terhadap penyerapan tenaga kerja. Dan untuk sisanya yang sebesar $0,18 \%$ merupakan kontribusi dari variabel lainnya yang tidak terdapat dalam penelitian ini.

\section{Pembahasan}

Pada analisis regresi data panel dengan model Fixed Effect telah memberikan gambaran untuk melihat pencapaian hipotesis yang telah dibuat yaitu pengaruh upah, investasi, PDRB dan teknologi terhadap penyerapan tenaga kerja. Untuk mengetahui pengaruh keempat variabel independen tersebut akan dijelaskan berdasarkan hasil analisis data yang telah dilakukan oleh peneliti berikut ini.

\section{Pengaruh Upah Minimum Terhadap Penyerapan Tenaga Kerja}

Berdasar dari hasil pengujian yang sudah dilakukan menunjukkan bahwa Upah Minimum (X1) tidak memiliki pengaruh dan tidak signifikan terhadap penyerapan tenaga kerja. Hasil ini menyatakan bahwa adanya peningkatan upah tidak mempengaruhi penyerapan tenaga kerja yang ada di Indonesia. Sebagai contoh dapat dilihat di Provinsi Nusa Tenggara Barat, pada tahun 2016 sampai tahun 2018 penyerapan tenaga kerja mengalami penurunan setiap tahunnya sedangkan upah minimum di daerah tersebut setiap tahun mengalami kenaikan. Hasil dari penelitian ini bertentangan dengan penelitian-penelitian sebelumnya, dan juga tidak sejalan dengan teori klasik yang menyatakan bahwa upah yang lebih tinggi menyebabkan penambahan jumlah tenaga kerja dalam proses produksi. Disetiap tahun upah minimum mengalami peningkatan hingga saat ini, akan tetapi pada tahun 2020 jumlah pengangguran juga meningkat. Hasil ini tidak sama dengan hipotesis yang diajukan oleh peneliti, maka dari itu hipotesis peneliti ini tidak diterima.

\section{Pengaruh Investasi Terhadap Penyerapan Tenaga Kerja}

Berdasarkan hasil uji yang dilakukan oleh peneliti menunjukkan bahwa Investasi (X2) 
memiliki pengaruh dan signifikan terhadap penyerapan tenaga kerja. Dengan kata lain, daerah yang memiliki investasi lebih tinggi sebesar $1 \%$ cenderung memiliki penyerapan tenaga kerja yang lebih tinggi sebesar 0.640027 atau 64.00\%. Dengan ini meunjuukan bahwa dengan terjadinya kenaikan nilai investasi menimbulkan kenaikan angka penyerapan tenaga kerja, sehingga angka pengangguran di Indonesia berkurang. Dapat dilihat investasi di Provinsi Jawa Timur pada tahun 2015 sampai tahun 2019 selalu naik dan juga diiringi dengan kenaikan penyerapan tenaga kerjanya.

Hasil penelitian ini didukung penelitian yang dilakukan oleh (Sulistiawati, 2012) yang hasilnya yaitu investasi memiliki pengaruh yang signifikan terhadap penyerapan tenaga kerja. Hasil dari penelitian ini juga sesuai dengan teori yang dikemukakan oleh Harrod-Domar yang menyatakan bahwa dengan adanya investasi dapat memperbesar kapasitas produksi, sehingga mengakibatkan adanya penambahan tenaga kerja (Jhingan, 2016). Hasil ini sama dengan hipotesis yang diajukan oleh peneliti, maka hipotesis penelitian ini dapat diterima.

\section{Pengaruh PDRB Terhadap Penyerapan Tenaga Kerja}

Berdasar dari hasil pengujian yang sudah dilakukan oleh peneliti menunjukkan hasil yaitu PDRB (X3) tidak memiliki pengaruh dan tidak signifikan terhadap penyerapan tenaga kerja. Hasil ini menunjukkan bahwa adanya kenaikan pada nilai PDRB tidak memiliki pengaruh terhadap penyerapan tenaga kerja yang ada di Indonesia. Seperti yang terjadi pada variabel upah minimum, PDRB di Provinsi Nusa Tenggara Barat pada tahun 2016 sampai tahun 2018 mengalami peningkatan, namun penyerapan tenaga kerjanya mengalami penurunan. Hasil penelitian ini bertentangan dengan penelitian sebelumnya, dan juga tidak sejalan dengan hukum Okun (Okun's Law) yang menjelaskan tentang pengaruh PDRB terhadap penyerapan tenaga kerja, yaitu jika PDRB disuatu wilayah naik maka penyerapan tenaga kerja di wilayah tersebut akan naik. Hasil ini tidak sama dengan hipotesis yang diajukan oleh peneliti, maka dari itu hipotesis peneliti tidak dapat diterima.

\section{Pengaruh Indeks Teknologi Terhadap Penyerapan Tenaga Kerja}

Berdasar dari hasil pengujian yang dilakukan oleh peneliti menunjukkan hasil indeks teknologi (X4) memiliki pengaruh positif dan signifikan terhadap penyerapan tenaga kerja. Sama halnya dengan investasi, indeks teknologi di Provinsi Jawa Timur pada tahun 2015 sampai tahun 2019 juga mengalamai kenaikan diikuti dengan angka penyerapan tenaga kerjanya. Hasil dari penelitian ini didukung dari hasil penelitian yang dilakukan oleh (Hasna, 2020) yaitu teknologi memiliki pengaruh positif dan signifikan terhadap penyerapan tenaga kerja. Dan juga sejalan dengan penjelasan dari (Sukirno, 2006) yaitu kemajuan teknologi memungkinkan kegiatan ekonomi yang awal mulanya menggunakan binatang dan manusia menjadi tenaga mesin, dengan jika apabila suatu perusahaan menggunakan teknologi padat modal, maka permintaan tenaga kerja akan menurun, sedangkan industri yang menggunakan teknologi padat karya maka permintaan tenaga kerja akan meningkat. Dengan adanya peningkatan teknologi yang digunakan dalam proses produksi maka akan mempercepat proses produksinya dan dapat memenuhi pesanan dalam jumlah yang besar. Meskipun dalam proses produksi menggunakan teknologi yang modern namun pengoperasian mesin masih ada beberapa yang dioperasikan oleh manusia, sehingga pemabahan tenaga kerja tetap diperlukan. Hasil ini sesuai dengan hipotesis yang diajukan oleh peneliti, oleh karena itu hipotesis dapat diterima.

5. Pengaruh Upah Minimum, Investasi, PDRB dan Indeks Teknologi Terhadap Penyerapan Tenaga Kerja

Berdasarkan uji $\mathrm{F}$ yang telah dilakukan oleh peneliti menunjukkan bahwa semua variabel independen berpengaruh terhadap variabel dependen. artinya, variabel upah minimum, investasi, PDRB dan indeks teknologi berpengaruh terhadap penyerapan tenaga kerja. Dalam hal ini dapat dilihat di Provinsi Banten pada tahun 2015 sampai tahun 2019, upah minimum, investasi, PDRB dan indeks teknologinya mengalami peningkatan disetiap tahun, dan diiringi dengan penyerapan tenaga kerjanya. Hasil ini sejalan dengan teori yang dikemukan oleh 
peneliti pada latar belakang, bahwa semua teori tiap-tiap variabel memiliki pengaruh terhadap penyerapan tenaga kerja. Sama halnya dengan keadaan ketenagakerjaan Indonesia pada tahun 2015-2019, upah tiap tahun mengalami kenaikan begitu juga dengan nilai investasi, PDRB dan teknologi yang digunakan juga meningkat namun angka pengangguran menurun, ini menunjukkan bahwa antara upah, inestasi, PDRB dan teknologi mempengaruhi penyerapan tenaga kerja di Indonesia.

\section{Simpulan}

Berdasarkan model terpilih model Fixed Effect dalam analisis regresi data panel, secara bersama-sama variabel upah minimum, investasi, PDRB dan indeks teknologi berpengaruh terhadap penyerapan tenaga kerja di Indonesia. Selain itu dari hasil analisis dan pembahasan diatas dapat disimpulkan yaitu upah minimum dan PDRB tidak memiliki pengaruh terhadap penyerapan tenaga kerja. Pada penelitian yang telah dilakukan upah minimum dan PDRB berpengaruh terhadap penyerapan tenaga kerja, berbeda dengan penelitian yang dilakukan saat ini bahwa upah minimum dan PDRB tidak berpengaruh terhadap penyerapan tenaga kerja. Hal ini terjadi karena pertumbuhan ekonomi hanya menekankan terhadap pertumbuhan output secara keseluruhan tanpa melihat dari proses suatu produksi. Meskipun adanya peningkatan pada upah dan nilai PDRB tidak memaksimalakan nilai penyerapan tenaga kerja, sehingga akan berdampak pada peningkatan pengangguran. Selain itu, investasi dan indeks teknologi berpengaruh terhadap penyerapan tenaga kerja di Indonesia. Semakin tinggi nilai investasi yang ada dilndonesia, maka penyerapan tenaga kerja akan mengalami peningkatan. Dengan adanya investasi akan memungkinkan untuk terbentuknya lapangan kerja yang baru sehingga dapat menyerap tenaga kerja secara maksimal.

Berdasarkan kesimpulan diatas, penulis menyarankan agar pemerintahan dapat mengundang investor dalam negeri maupun investor asing untuk menanam modal di Indonesia. Dengan investasi tersebut dapat digunakan untuk membuka lapangan pekerjaan baru sehingga penyerapan tenaga kerja dapat dimaksimalkan dan mengurangi angka pengangguran. Model penelitian ini masih memiliki kekurangan dan sangat terbatas dikarenakan variabel yang digunakan masih sebatas melihat apakah ada pengaruh antara upah minimum, investasi, PDRB dan indeks teknologi terhadap penyerapan tenaga kerja di Indonesia. Sehingga masih dibutuhkan penelitian lanjutan untuk membahas lebih dalam mengenai variabel lain yang diduga memiliki keterkaitan dengan penyerapan tenaga kerja, sehingga dapat dijadikan untuk pelengkap penelitian terdahulu dan dapat digunakan sebagai acuan pihak yang membutuhkan dan mengambil keputusan terkait dengan permasalah tenaga kerja.

\section{Daftar Pustaka}

Ali, G. et al. (2020). Pengaruh Produk Domestik Regional Bruto (PDRB) dan Investasi Terhadap Penyerapan Tenaga Kerja Di Kabupaten Minahasa Selatan . Jurnal Berkala Ilmiah Eisiensi. 20 (01), 1-11.

Arsyad, L. (2010). Ekonomi Pembangunan. Yogyakarta: UPP STIM YKPN.

BPS Indonesia. Statistik Indonesia 2016. Jakarta: BPS

BPS Indonesia. Statistik Indonesia 2017. Jakarta: BPS

BPS Indonesia. Statistik Indonesia 2018. Jakarta: BPS

BPS Indonesia. Statistik Indonesia 2019. Jakarta: BPS

BPS Indonesia. Statistik Indonesia 2020. Jakarta: BPS 
BPS Indonesia. Statistik Indonesia 2021. Jakarta: BPS

Cahyadi L. D. C. (2018). Analisis Faktor Yang Mempengaruhi Penyerapan Tenaga Kerja Industri Kreatif Di Kota Denpasar. Prosiding Sintesa.

Feriyanto, N. (2014). Ekonomi Sumber Daya Manusia Dalam Perspektif Indonesia. UPP STIM YKPN.

Hanuraga, M. (2018). Pengaruh Upah Minimum Provinsi Terhadap Penyerapan Tenaga Kerja Sektor Kontruksi Di Indonesia: Studi 6 Provinsi Di Jawa. Skripsi. Universitas Jember.

Kuncoro, H. (2002). Upah Sistem Bagi Hasil dan Penyerapan Tenaga Kerja.Jurnal Ekonomi Pembangunan. Kajian Ekonomi Negara Berkembang. 7 (1), 45-46.

Hasna, Y. M. (2020). Pengaruh Tingkat Upah dan Teknologi Terhadap Penyerapan Tenaga Kerja Pada Industri Kerajinan Kulit Di Kabupaten Magetan. Skripsi. IAIN Ponorogo

Indradewa, I. G. A., \& Natha, K. S. (2013). Pengaruh Inlasi, PDRB dan Upah Minimum Terhadap Penyerapan Tenaga Kerja Di Provinsi Bali. E-jurnal EP Unud, 4(8). 923-950.

Jhingan, M. L. (2016). Ekonomi Pembangunan dan Perencanaan. Rajawali Pers.

Konadi, W. (2014). Analisis Kredit Investasi Perbankan terhadap Penyerapan Tenaga Kerja. Jurnal Kebangsaan .03 (06).

Lavianty, M. E. (2016). Pengaruh Pdrb, Investasi, Upah Dan Inflasi Terhadap Penyerapan Tenaga Kerja Di Pulau Jawa Tahun 2008-2013. Skripsi. Universitas Pasundan Bandung.

Mankiw, N. G. (2006). Makro Ekonomi (keenam). erlangga.

Nurfiat, N. A \& Rustariyuni, S. D. (2018). Pengaruh upah dan teknologi terhadap produktivitas dan penyerapan tenaga kerja pada industri mebel di kota denpasar. Piramida. 14(1), 34-48.

Rahmawati, I. (2019). Pengaruh Upah Minimum, Produk Domestik Regional Bruto (PDRB), Dan Investasi Terhadap Penyerapan Tenaga Kerja Di Provinsi Jawa Timur. Skripsi. Universitas Jember

Sasana, H. (2009). Analisis dampak pertumbuhan ekonomi, kesenjangan antar daerah dan tenaga kerja terserap terhadap kesejahteraan di kabupaten/kota provinsi jawa tengah dalam era desentralisasi fiskal. Jurnal Bisnis dan Ekonomi. 16(1), 50-69.

Simanjuntak, Payaman. J. (2001). Pengantar Ekonomi Sumberdaya Manusia. Lembaga Penerbit FEUI. Jakarta.

Sinclair, T. (2005). Permanent and transitory movements in output and unemployment: Okun's law persists. George Washington University, Manuscript.

Sugiyono. (2016). Penelitian Kuantitatif, Kualitatif, dan R\&D. Alfabeta.

Sukirno, S. (2006). Mikroekonomi Teori Pengantar. Raja Grafindo Persada.

Sulistiawati, R. (2012). Pengaruh Investasi terhadap Pertumbuhan Ekonomi dan Penyerapan Tenaga Kerja Serta Kesejahteraan Masyarakat di Provinsi di Indonesia. Jurnal Ekonomi Bisnis dan Kewirausahaan. 3(1), 29-50.

Todaro, M.P. (2000). Economic Development in the Third World. Seventh Edition. Pearson Ed95 
ucation Limited, New York.

Undang - undang Republik Indonesia Nomor 13 tahun 2003 tentang Ketenagakerjaan.

Widarjono, A. (2013). Ekonometrika: Pengantar dan Aplikasinya. Ekonosia.

Widdyantoro, A. (2013). Pengaruh PDB, Investasi, Dan Jumlah Unit Usaha Terhadap Penyerapan Tenaga Kerja Usaha Kecil Dan Menengah Di Indonesia Periode 2000-2011. Skripsi. UIN Syarif Hidayatullah Jakarta.

Zheleznikova, E. (2013). The Development Of The Forms Of Collective Labour Organization At The Enterprise. International Journal of Economics and Financial Issues, 2, pp: 43. 